\title{
Vitamin D supplements' effect on expediting the weaning process in patients with the stroke
}

\author{
Mahzad Yousefian ${ }^{1}$, Seiyede Roshanak Gholzar Pour Sadegi², Mehran Sakaki ${ }^{3}$
}

\begin{abstract}
Faster weaning from mechanical ventilation in ICU reduces the side effects of long-term mechanical ventilation and the cost of admission to the hospital. The objective of this study was to investigate the effect of vitamin D supplement on the facilitation of weaning in the stroke patients. In this study 99 stroke patients who were admitted to the ICU and intubated due to a fall in their level of consciousness entered the study. The level of 25 (oh) D was assessed in all of the patients and then they were divided into two different groups based on their level of vitamin $D$. Those included in group A ( 33 patients) had the vitamin D level of higher than $20 \mathrm{ng} / \mathrm{ml}$ and those in the other group (66 patients) had the vitamin D level of lower than $20 \mathrm{ng} / \mathrm{ml}$ who themselves were further divided into the two groups of $B$ and $C$ randomly (each consisting of 33 patients). The patients in group $B$ received intramuscular vitamin $\mathrm{D} 3$ and tablet of calcium $\mathrm{D}$. In the meantime, placebo was administered to the patients in group $C$. At the end of the intervention the mean level of vitamin $D$ was $28.04 \pm 10.3 \mathrm{ng} / \mathrm{ml}$ in group $A, 8.85 \pm 2.3 \mathrm{ng} / \mathrm{ml}$ in group $B$, and $10.52 \pm 4.81 \mathrm{ng} / \mathrm{ml}$ in group $C$. The mean durations of intubation for patients in groups $A, B$, and $C$ were 13.81 days, 15.96 days, and 15 days, respectively. The patients in group A had the least duration of intubation. The three groups were significantly different as regards the duration of patients' intubation $(p<0.05)$. However, the difference between groups $B$ and $C$ was not statistically significant $(p>0.05)$. The results of this study indicate the effect of vitamin $D$ on accelerating the weaning of patients in the intensive care unit in stroke patients.
\end{abstract}

Keywords: weaning, vitamin D, stroke

\section{INTRODUCTION}

Mechanical ventilation is one of the most common forms of medical treatment prescribed for patients admitted to Intensive Care Unit (ICU) (1).

More than $90 \%$ of adult patients in critical condition need mechanical ventilation in ICU. However, it might cause adverse effects in their cardiovascular system, respiratory system, gastrointestinal tract, musculoskeletal system, water and electrolyte status, and psychological condition on the one hand and increase healthcare costs on the other (2). Currently, cerebrovascular diseases are the second leading cause of death and the sixth most common cause of disability in the world. Investigations suggest that they will become the $4^{\text {th }}$ leading cause of disability by 2020 (3). Each year, stroke causes the death of 5.5 million people in the world more than two thirds of which occur in developing countries. In Iran, it also causes the death of thousands of people each year $(4,5)$.

In industrial countries, the prevalence of stroke is 5 per 1000 population while in developing countries it is $5-10$ per 1000 population (7).

Vitamin $D$ is a fat-soluble vitamin which plays an important role in regulating the level of calcium in the blood. Its storage form is 25 (oh) $D$ and its level in the blood depends on the radiation of ultraviolet rays to the skin and the reception of sufficient food and nutritional supplements (8).

Lower than $20 \mathrm{ng} / \mathrm{ml}$ serum levels of 25 (oh) Dare considered vitamin D deficiency; levels in the range of 21-29 ng/ml are regarded as ineffective; and levels above $30 \mathrm{ng} / \mathrm{ml}$ are considered to be the sufficient level of vitamin $D(9,10)$.

\footnotetext{
1 Assistant Professor of Anesthesiology, Department of Anesthesiology, School of Medicine, Ardabil University of Medical Sciences, Ardabil, Iran

2 General Physician, Ardabil University of Medical Sciences, Ardabil, Iran

3 Pathologist, Department of Pathology, Ardabil University of Medical Sciences, Ardabil, Iran
}

Correspondence: Mahzad Yousefian

Assist Professor of Anesthesiology, Department of Anesthesiology, School of medicine, Ardabil University of Medical Sciences, Ardabil, Iran.

E-mail:dr_mahzad@yahoo.com

Received: 8 Apr 2018, Accepted: 12 Jul 2018

(C) 2019 by the authors; licensee Modestum Ltd., UK. This article is an open access article distributed under the terms and conditions of the Creative Commons Attribution License (http://creativecommons.org/licenses/by/4.0/). 
In a study which was conducted in Isfahan, Iran, $93.5 \%$ of the total 158 ICU patients under study suffered from vitamin $D$ deficiency (11). Patients in critical condition who are hospitalized in ICU suffer from vitamin D deficiency for various reasons. Besides being in critical condition, therapeutic measures such as surgery, liquid therapy, cardiovascular bypass, and plasma replacement may reduce their vitamin D level. In addition, patients hospitalized in ICU are at greater risks of disruption in vitamin $\mathrm{D}$ axis due to decreased contact with sunlight, immobilization, the increase in the conversion of 25 (oh) $\mathrm{D}$ to 1.25 (oh) $\mathrm{D}_{3}$, inflammation, disruptions in the liver, parathyroid, and renal functions, reduced resistance of body organs, and nutritional deficiencies $(12,13)$.

In their study, Verceles et al. demonstrated that there is a significant relationship between vitamin $D$ deficiency and the need for long-term respiratory protection. However, they observed no relationship between the level of 25 (oh) $D$ and successful weaning from mechanical ventilation (14). Bearing these in mind, we aimed in this study to investigate the effect of vitamin D supplement on the facilitation of weaning in the stroke patients hospitalized at the ICU of Alavi Hospital in Ardabil, Iran.

\section{METHODS}

In this study which was a clinical trial, 99 stroke patients who were admitted to the ICU of Alavi Hospital in Ardabil in the first half of 1396 and intubated due to a fall in their level of consciousness entered the study. Patients were selected using convenience sampling method and entered the study after achieving consent from their relatives. Sampling process continued until the desired sample size was reached. The inclusion criteria were being at the age of 20 years or more, suffering from stroke, and being intubated. The exclusion criteria, on the other hand, were death during the first 48 hours after stroke, pregnancy, being under treatment with vitamin D supplement, having pulmonary diseases, consuming corticosteroid, having malabsorption syndrome, suffering from chronic kidney diseases, and having metastatic cancer.

The information about the age, gender, and underlying diseases of the patients was collected using a questionnaire. Furthermore, the information about their serum level of vitamin D was collected from the laboratory test results obtained for each patient.

The level of $25(\mathrm{oH}) \mathrm{D}$ was assessed in all of the patients and then they were divided into two different groups based on their level of vitamin D. Those included in group A (33 patients) had the vitamin D level of higher than $20 \mathrm{ng} / \mathrm{ml}$ and those in the other group (66 patients) had the vitamin $D$ level of lower than $20 \mathrm{ng} / \mathrm{ml}$ who themselves were further divided into the two groups of $B$ and $C$ randomly (each consisting of 33 patients). The patients in group $B$ received vitamin D3 300,000 IU through intramuscular injection up to three doses per week as well as a tablet of calcium D (500 $\mathrm{mg}$ ) on a daily basis. During this time, placebo was administered to the patients in group $\mathrm{C}$. At the end of the intervention, the success of weaning and the time needed for its implementation were compared in the three groups.

\section{STATISTICAL ANALYSIS}

The results were reported as mean \pm standard deviation (SD) for the quantitative variables and percentages for the categorical variables. The groups were compared using Anova the t-test.

A P value $\leq 0.05$ was considered statistically significant. All the statistical analyses were performed using SPSS version 16.0 (SPSS Inc., Chicago, IL, USA) for Windows.

\section{RESULTS}

According to the data collected through questionnaires, 13 patients $(13.13 \%)$ were distributed in the age range of 21-40 years, 31 patients (31.31\%) in the age range of $41-60$ years, 41 patients $(41.41 \%)$ in the age range of $61-80$ years, and 14 patients (14.14\%) in the age range of $81-100$ years. The mean age of the patients was 60.64 years. The differences among the groups as regards the age distribution were found to be statistically significant $(p<0.05)$.

From the patients investigated in this study, 54 cases (54.54\%) were male and 45 cases (45.45\%) were female. The differences among the groups as regards the number of patients with different genders were also found to be statistically significant. The gender distribution of patients in the groups under study is presented in Table 1. 
Table 1: The results of the variables in the studied groups

\begin{tabular}{|c|c|c|c|c|c|}
\hline & & \multicolumn{3}{|c|}{ Group } & \multirow{2}{*}{$\mathbf{P}$} \\
\hline & & A & B & C & \\
\hline & Age & 45.21 & 69.87 & 66.84 & .033 \\
\hline \multirow{2}{*}{ Gender } & male & $16(16.16 \%)$ & $20(20.20 \%)$ & $18(20.20 \%)$ & \multirow{2}{*}{.042} \\
\hline & female & $17(17.17 \%)$ & $13(20.20 \%)$ & $15(20.20 \%)$ & \\
\hline & Vit D (ng/ml) & $28.04 \pm 10.3$ & $8.85 \pm 2.3$ & $10.52 \pm 4.81$ & \\
\hline \multirow{11}{*}{$\begin{array}{c}\text { history of } \\
\text { previous illness }\end{array}$} & $\begin{array}{c}\text { Hypertension } \\
\end{array}$ & $10(10.10 \%)$ & $10(10.10 \%)$ & $11(11.11 \%)$ & \multirow{11}{*}{.085} \\
\hline & Diabetes & $2(2.02 \%)$ & $4(4.04 \%)$ & $5(5.05 \%)$ & \\
\hline & CVA & $1(1.01 \%)$ & $5(5.05 \%)$ & $3(3.03 \%)$ & \\
\hline & Ischemic heart disease & $1(1.01 \%)$ & $1(1.01 \%)$ & $1(1.01 \%)$ & \\
\hline & Coronary artery disease & $1(1.01 \%)$ & $3(3.03 \%)$ & $1(1.01 \%)$ & \\
\hline & $\begin{array}{l}\text { ESRD } \\
\end{array}$ & $1(1.01 \%)$ & 0 & $1(1.01 \%)$ & \\
\hline & leukemia & 0 & 0 & $1(1.01 \%)$ & \\
\hline & Peritonitis & 0 & $1(1.01 \%)$ & 0 & \\
\hline & Cholecystitis & 0 & $1(1.01 \%)$ & 0 & \\
\hline & Other causes & 0 & $4(4.04 \%)$ & $3(3.03 \%)$ & \\
\hline & No history of previous illness & $20(20.2 \%)$ & $10(10.10 \%)$ & $10(10.1 \%)$ & \\
\hline \multirow{3}{*}{ stroke } & Intubation days & 13.81 & 15.96 & 15 & .032 \\
\hline & Ischemic & $25(25.25 \%)$ & $24(24.24 \%)$ & $25(25.25 \%)$ & \multirow{2}{*}{.13} \\
\hline & Hemoragic & $8(8.08 \%)$ & $9(9.09 \%)$ & $8(8.08 \%)$ & \\
\hline
\end{tabular}

Table 2: Duration of intubation in the studied groups (day)

\begin{tabular}{ccccccccc}
\hline \multirow{2}{*}{ Group } & $\begin{array}{c}\text { Day } \\
\text { sex }\end{array}$ & $\mathbf{1 - 1 0}$ & $\mathbf{1 1 - 2 0}$ & $\mathbf{2 1 - 3 0}$ & $\mathbf{3 1 - 4 0}$ & $\mathbf{4 1 - 5 0}$ & $<\mathbf{5 1}$ & \multirow{2}{*}{ Death } \\
\hline \multirow{2}{*}{ A } & male & $0(0 \%)$ & $10(10.1 \%)$ & $3(3.03 \%)$ & $0(0 \%)$ & $0(0 \%)$ & $4(4.04 \%)$ & $0(0 \%)$ \\
\cline { 2 - 9 } & female & $1(1.01 \%)$ & $11(11.11 \%)$ & $2(2.02 \%)$ & $0(0 \%)$ & $0(0 \%)$ & $2(2.02 \%)$ & $0(0 \%)$ \\
\hline \multirow{2}{*}{ B } & male & $0(0 \%)$ & $3(3.03 \%)$ & $4(4.04 \%)$ & $4(4.04 \%)$ & $0(0 \%)$ & $4(4.04 \%)$ & $5(\% 5.05)$ \\
\cline { 2 - 9 } & female & $0(0 \%)$ & $2(2.02 \%)$ & $3(3.03 \%)$ & $0(0 \%)$ & $2(2.02 \%)$ & $1(\% 1.01)$ & $3(3.03 \%)$ \\
\hline \multirow{2}{*}{ C } & male & $0(0 \%)$ & $3(3.03 \%)$ & $3(3.03 \%)$ & $3(3.03 \%)$ & $0(0 \%)$ & $5(\% 5.05)$ & $4(4.04 \%)$ \\
\cline { 2 - 9 } & female & $1(\% 1.01)$ & $4(4.04 \%)$ & $6(6.06 \%)$ & $1(\% 1.01)$ & $1(\% 1.01)$ & $0(0 \%)$ & $2(2.02 \%)$ \\
\hline
\end{tabular}

Among the patients under study, 74 cases $(74.74 \%)$ suffered from ischemic stroke and 25 cases (25.25\%) suffered from hemorrhagic stroke. There was no statistically significant difference among the groups as regards the types of stroke $(p>0.05)$.

$10.1 \%$ of the patients in groups B and C and $20.2 \%$ of the patients in group A had no history of previous illnesses. The most prevalent underlying disease in the patients under study was hypertension which was observed in $10.1 \%$ of the patients in groups $A$ and $B$ and $11.11 \%$ of the patients in group C. $1.01 \%$ of the patients in group $A, 5.05 \%$ of the patients in group $B$, and $3.03 \%$ of the patients in group $C$ had a history of previous stroke (Table 1). As to the previous illnesses and underlying diseases, no significant difference was observed among the groups $(p>0.05)$.

The mean level of vitamin D was $28.04 \pm 10.3 \mathrm{ng} / \mathrm{ml}$ in group $A, 8.85 \pm 2.3 \mathrm{ng} / \mathrm{ml}$ in group $B$, and $10.52 \pm 4.81 \mathrm{ng} / \mathrm{ml}$ in group C (Table 1). The differences among the groups in this regard turned out to be statistically significant $(p<0.05)$. Figure 2 shows the distribution of patients in terms of their serum level of vitamin $D$.

The mean durations of intubation for patients in groups A, B, and C were 13.81 days, 15.96 days, and 15 days, respectively (Tables 1 and 2). The patients in group A had the least duration of intubation. The three groups were significantly different as regards the duration of patients' intubation $(p<0.05)$. However, the difference between groups $B$ and $C$ was not statistically significant $(p>0.05)$.

\section{DISCUSSION}

Pulmonary function plays a vital role in the successful isolation of patients from long-term mechanical ventilation known as weaning $(15,16)$. Vitamin D deficiency is common in ICU patients who need long-term mechanical ventilation. Therefore, it is logical to expect a higher probability of successful weaning in patients with higher concentrations of 25 (oH) D (14).

In a study which was conducted by Verceles et al., a number of ICU patients needing long-term mechanical ventilation were investigated for the relationship between concentration of 25 (oh) D and successful weaning. They divided the patients into two groups based on their 25 (oh) D concentration (those with vitamin levels of higher than $20 \mathrm{ng} / \mathrm{ml}$ were assigned to normal group and those with lower levels than that were assigned to deficiency group). Then, the relationship 
between the concentration of this vitamin and weaning was investigated. From the total number of 183 patients studied by them, $61 \%$ suffered from vitamin $D$ deficiency. However, they observed no significant relationship between the concentration of vitamin D and successful weaning (14). This finding, however, is inconsistent with the findings obtained in our study.

In another study which was conducted by Inamo et al. in a pediatric hospital in Japan, it was revealed that the level of vitamin $D$ is quite low in patients with lower respiratory tract infections and that there is a significant relationship between the deficiency of this vitamin and the need for respiratory protection (17). Similarly, in a meta-analysis conducted by Gaksch et al., a significant relationship was found between vitamin D deficiency and the increase in mortality and morbidity among critically ill patients (18).

In our study, the patients with normal level of vitamin $D$ were isolated from mechanical ventilation system significantly faster than those who suffered from vitamin D deficiency. In patients with vitamin D deficiency, even the prescription of this vitamin could not reduce the duration of intubation. Put another way, the intubated patients who had a normal level of vitamin $D$ at the beginning of hospitalization had better weaning compared to those who suffered from vitamin $D$ deficiency.

Given the importance of patients' faster weaning from mechanical ventilation in ICU and the relationship between lower levels of vitamin $D$ and the prolongation of weaning process which itself leads to an increase in the duration of ventilator dependency and prolongs hospitalization in ICU, it seems that by conducting more studies on this issue with larger sample sizes, more effective ways can be identified so as to increase the level of vitamin $D$ in such patients.

\section{ACKNOWLEDGEMENT}

This article has is extracted from the Medicine thesis, Ardabil university of medical science, Ardabil, Iran.

The authors would like to thanks subjects who willingly participated in the study.

\section{REFERENCES}

1. Chaiwat O, Sarima N, Niyompanitpattana K, Komoltri C, Udomphorn Y, Kongsayreepong S. Protocol-Directed vs. Physician-Directed Weaning from Ventilator in Intra-Abdominal Surgical Patients .J Med Assoc Thai. 2010;93(8): 930-6. PMid:20718169

2. McLean SE, Jensen LA, Schroeder DG, Gibney NR, Skjodt NM. Improving Adherence to a Mechanical Ventilation Weaning Protocole Critically III Adults: Outcomes after an Implementation Program. Am J Crit Care. 2006;15(3): 299-309. PMid:16632772

3. Menken M, Munsat TL, Toole JF. The global burden of disease study: implications for neurology. Arch Neurol. 2000;57(3):418-420. https://doi.org/10.1001/archneur.57.3.418 PMid:10714674

4. Greenberg D,Aminof M, Simon R. Clinical neurology. 8th ed. New York: McGraw Hill, 2012.

5. Haacke C, Althaus A, Spottke A, Siebert U, Back T, Dodel R. Long-Term outcome after stroke evaluating healthrelated quality of life using utility measurements. Stroke. 2006;37:193-8. https://doi.org/10.1161/01.STR.0000196990.69412.fb PMid:16339458

6. Chong JY, Sacco RL. Epidemiology of stroke in young adults: race/ethnic differences. J Thromb Thrombolysis. 2005;20(2):77-83. https://doi.org/10.1007/s11239-005-3201-9 PMid:16205856

7. Poungvarin N. Stroke in the developing world. Lancet. 1998;352(Suppl 3):SIII19-SIII22.

8. Venkatram S, Chilimuri S, Adrish M, Salako A, Patel M, Diaz-Fuentes G. Vitamin D deficiency is associated with mortality in the medical intensive care unit. Critical Care. 2011;15(6):292. https://doi.org/10.1186/cc10585 PMid:22152332 PMCid:PMC3388639

9. Holick MF. Vitamin D deficiency. New Eng J Med. 2007;357(3):266-81. https://doi.org/10.1056/NEJMra070553 PMid:17634462

10. Christakos S, Ajibade DV, Dhawan P, Fechner AJ, Mady L. Vitamin D:metabolism. Rheumatic Dis Clin North Am. 2012;38(1):1-11. https://doi.org/10.1016/j.rdc.2012.03.003 PMid:22525839

11. Amrein K, Christopher KB, McNally JD. Understanding vitamin D deficiency in intensive care patients. Intensive Care Med. 2015;41(11):1961-4. https://doi.org/10.1007/s00134-015-3937-4 PMid:26142054

12. Rojek-Jarmuła A, Hombach R, Krzych $\succeq$. Does the APACHE II score predict performance of activities of daily living in patients discharged from a weaning center? Kardiochirurgia i Torakochirurgia Polska. 2016;13(4):353-8. https://doi.org/10.5114/kitp.2016.64880 
13. Barnett N, Zhao Z, Koyama T, Janz DR, Wang C-Y, May AK, et al. Vitamin D deficiency and risk of acute lung injury in severe sepsis and severe trauma: a case-control study. Annals of intensive care. 2014;4(1):1. https://doi.org/10.1186/2110-5820-4-5 PMid:24559079 PMCid:PMC3944729

14. Verceles AC, Weiler B, Koldobskiy D, Goldberg AP, Netzer G, Sorkin JD. Association between vitamin D status and weaning from prolonged mechanical ventilation in survivors of critical illness. Respiratory care. $2015 \mathrm{Jul}$ 1;60(7):1033-9. https://doi.org/10.4187/respcare.03137 PMid:25715347 PMCid:PMC4485581

15. Rieves RD, Bass D, Carter RR, Griffith JE, Norman JR. Severe COPD and acute respiratory failure. Correlates for survival at the time of tracheal intubation. Chest. 1993;104(3):854-60. https://doi.org/10.1378/chest.104.3.854 PMid:8365300

16. Menzies R, Gibbons W, Goldberg P. Determinants of weaning and survival among patients with COPD who require mechanical ventilation for acute respiratory failure. Chest. 1989; 95(2):398-405. https://doi.org/10.1378/chest.95.2.398 PMid:2914493

17. Inamo $Y$, Hasegawa M, Saito K, Hayashi R, Ishikawa T, Yoshino Y, Hashimoto K, Fuchigami T. Serum vitamin D concentrations and associated severity of acute lower respiratory tract infections in Japanese hospitalized children. Pediatr Int. 2011 Apr 1;53(2):199-201. https://doi.org/10.1111/j.1442-200X.2010.03224.x PMid:21648117

18. Gaksch M, Jorde R, Grimnes G, Joakimsen R, Schirmer H, Wilsgaard T, Mathiesen EB, Njølstad I, Løchen ML, März W, Kleber ME. Vitamin D and mortality: Individual participant data meta-analysis of standardized 25hydroxyvitamin D in 26916 individuals from a European consortium. PloS one. 2017 16;12(2):e0170791.

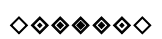

http://www.ejgm.co.uk 